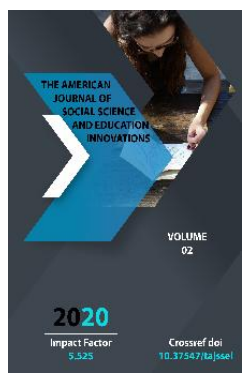

\title{
The Importance Of The Discussion Method In The Development Of Argumentative Competence In Students
}

\author{
Turabova Sevara Kattakulovna \\ Doctor Of Philosophy (Phd), Termez State University Termez, Uzbekistan
}

Journal Website:

http://usajournalshub.c

om/index,php/tajssei

Copyright: Original

content from this work

may be used under the

terms of the creative

commons attributes

4.0 licence.

\section{ABSTRACT}

This article discusses the importance of using debate as a teaching method in mastering key technologies to improve students' argumentative competence. At the same time, the ability to argue constructively is interpreted as the ability to perform various argumentative actions to substantiate or refute certain points of view. The article presents the characteristics of argumentative skills, as well as the conditions for the formation of logical and psychological components of debate, which is one of the specific manifestations of argumentation.

\section{KEYWORDS}

Debate, student, education, truth, evidence, constructive debate, argumentative competence, logical and psychological components, discussion skills.

\section{INTRODUCTION}

Argumentative competence is the ability to persuade the recipient of certain aspects of an event or situation by correctly and consciously using argumentative schemes and methods to advance and substantiate the thesis by the facilitator [1, 13]. Argumentation strategies are implemented as an example of the realization of certain communicative goals in 
the argumentation process. Since this article focuses on the problem of developing students' argumentative competence, we consider the debate as a" method that activates the learning process". It should be noted that the combination of argumentation and debate in a single study is based on the fact that they are closely interrelated as a means of communication. Argumentation is a method of reasoning that involves proving and refuting, in which process the truth of the thesis and the error of the antithesis are convinced in both the proponent and his opponents.

Debate as its private form of argumentation is its most serious and sharp form. In particular, the Russian logician S.I. Povarnin [2,] understands that the essence of argumentation is in competition.

Any evidence has its own subject or subject matter, and the argument is characterized by the existence of inconsistent assumptions about the same object and event. The study of the problem of argumentation is directly related to the consideration of the issue of the debate and the attempts to express the rules of its conduct. Because proof is often used in the very process of debate.

Debate is manifested in almost all types of argumentation. Therefore, in many cases, the types of arguments are replaced by types of arguments [3, 50]. Also, sometimes the differences between discussions, polemics, disputes, debates, which are specific manifestations of the debate, are not sufficiently disclosed, their relationship is not well defined.

We reflect on the subject of constructive debate and comment on constructive debate as a preliminary working definition: constructive debate is the most organized and systematic form of communication designed to seek out the truth by discussing problems in the process of research according to its logical nature. In a constructive debate, unlike other simple forms of debate, the phenomenon of constantly seeking evidence for both parties, confirming or denying them, choosing the optimal one plays an important role.

The ability to conduct debate constructively and effectively is important for many areas of practice. Because the main goal of constructive discussions is to find ways to solve the problem and seek mutual agreement and cooperation between the opposing parties to achieve a solution. Constructive debate is therefore, by its logical nature, the most organized and systematic form of communication designed to seek truth.

In the process of scientific learning through discussion, a research method is implemented in the form of creating models that can give a lot of answers to a question and approbating them when it is not possible to get a definite answer immediately. In the development of cognition in the form described above, the research function of the debate is realized. Therefore, the effectiveness of constructive debate is based on the fact that it is possible to approach from different positions in finding a solution to the problem, to maximize the scientific potential of many professionals, to abstract some points of view or to move away from the state of limitation.

The objectivity of the debate (in addition to the debate, there are a number of specific aspects of the debate, such as debate, controversy, dispute) is also determined by the existence of contradictory features, relationships, inherent in the objects, events 
and processes under study. The contradictory features inherent in them from the very beginning lead to the emergence of conflicting opinions, hypotheses, theories.

The causes of controversy are based on cognitive contradictions, paradoxes, antinomies. Debates are used to achieve a variety of goals, in particular: to identify and put a problem, find a solution, evaluate the point of view put forward, determine their level of truth, verify the evidence and the logical correctness of reasoning, discover new aspects of a problem, and so on. In the debate, "the question of truth is inextricably linked with the problem of proof. This is especially well understood in science, in its quest to establish its scientific laws [4, 98].

There are different approaches to the study of debate, each of which focuses on the study of the specific features of the debate. For example, when considering the logical structure of a debate, the ability to argue is interpreted as the ability to perform argumentative actions in justifying or rejecting a particular position. As one of the problembased teaching methods, the debating method is becoming increasingly relevant in career-oriented teaching. It should be noted that the debate method is one of the most important forms of teaching argumentative communication. The use of the discussion method serves as an effective tool for shaping the basic skills of public speaking and developing communicative competence in general, as discussion helps to develop reflexive thinking that reflects the basics of oral speech as well as direct language skills.

Let us now turn to the logical and psychological components of the debate.
The logical component of the discussion includes the logical skills involved in going through the stages of critical discussion. These logical skills include:

a) Be able to identify the thesis and form an antithesis;

b) Be able to discuss the thesis and antithesis;

c) Be able to evaluate the argumentative power of the thesis and antithesis;

d) Ability to determine the outcome of the discussion.

Psychological Component. N.I. Makhnovskaya considers the psychological component in the study of the problem of pedagogical argumentation in the field of professional speech as a psychological skill associated with different aspects of the communication process [5]. According to the researcher, the psychological component includes:

1) The ability to create a positive impression in return for appearance and selfexpression;

2) The ability to compose speech in a compositional way;

3) The ability to use clear and figurative vocabulary for the interlocutor;

4) The ability to use body language and sound in substantiating an opinion;

5) The ability to listen to the opponent as a necessary condition for the correct assessment of existing disagreements;

6) The ability to remain motivated to find a common ground or a mutually acceptable solution to a contentious issue. Ability to assess the motivation of the interviewee when he / she does not want to discuss the issue constructively and to withdraw from the discussion; 
7) The ability to deeply analyze the topic under discussion and to get the interviewee to a meaningful analysis;

8) The ability to control one's emotions as well as the ability to regulate the emotional state of the interlocutor.

Thus, skills $1-4$ are persuasive speech skills, and skills 5-7 are constructive interaction skills. The ability to demonstrate the power of argumentation effectively, that is, to go through the main stages of a discussion effectively, depends on having persuasive speaking skills. Convincing speech ensures the acceptability of an argument, whether an argument is accepted as a thesis or an antithesis. Constructive communication skills help to ensure the successful passage of all stages of the discussion and to ensure a defined sequence of steps. Thus, the effective structure of communicative communication depends on the communicative speaking ability formed. We support the opinion of researchers who believe that the unity of logical thinking with the meaningful structure of the debate is determined primarily by the clear questioning of the controversial question and the correct formulation of the discussion topic, the ability to construct ideas reasonably and the integration of the starting position. [6]. Awareness of discursive formulas is an integral part of reasoning skills, which allows us to better understand the content and purpose of the interlocutor's statements.

It should be noted that debating communication enhances students' independent thinking and learning activism and allows them to use this knowledge in their personal life experiences. Mastering the norms of rational communication and the rules of discussion, forms a responsible attitude to speech, as well as helps to develop the ability to quickly orient and manage them in changing information flows. This is one of the most important requirements for a modern specialist. All this encourages the main motives for the development of students 'argumentative competence in higher education institutions Thus, the study of debate as a teaching method allows us to conclude that it is an effective way to develop students' argumentative competence and intellectual thinking skills. As a result, students acquire basic technologies of evidence-based communication, as well as the ability to protect themselves from manipulative influences.

\section{REFERENCES}

1. Gavrilova A.N. Formirovaniye pismenno-rechevoy argumentativnoy kompetensii u studentov gumanitarnix spetsialnostey : Avtoref. dis. ... kand. ped. nauk. SPb., 2011.

2. Povarnin S.I. Iskusstvo spora: $\mathrm{O}$ teorii $\mathrm{i}$ praktike spora. - M., 1993. (Vosproizvedeno po 2-mu izd. Petrograd., 1923). GI.X. - S. 42.

3. Turobova S. Ilmiy bahs (debat, diskussiya, polemika,disput)ning mantiqiy-epistemik tahlili. Monografiya. Surxon-Nashr. -Termiz, $2020 \mathrm{y}$.

4. Sharipov M. Dialektik mantiqda haqiqat va isbotlash masalasi. Alisher Navoiy va falsafa tarixining dolzarb muammolar.// Ilmiy to'plam. - T.: Turon zamin ziyo, 2016. - B. 98.

5. Maxnovskaya N. I. Metodika obucheniya diskussii i diskussionnoy rechi studentov-filologov: Avtoref. dis. ... kand. ped. nauk. M., 1992. 
Doi: https://doi.org/10.37547/tajssei/Volume02Issue09-68

6. Morozova I.G. Ispolzovaniye diskussii na zanyatiyax inostrannogo yazika $v$ ramkax problemnogo obucheniya pri podgotovke sovremennix spesialistov // Inostrannie yaziki: Teoriya i praktika. № 1. Tezaurus, 2010 